\title{
DIE STAATKUNDIGE ERFENIS EN ONTWIKKELING VAN DIE REPUBLIEK VAN SUID-AFRIKA
}

Die opsteller van 'n referaat oor die staatkundige erfenis en ontwikkeling van die Republiek van Suid-Afrika moet noodwendig begin by 'n tydperk lank voordat Jan van Riebeeck in 1652 'n blanke volksplanting hier kom stig het. In sekere sin moet hy teruggaan na die tydperk toe die boeke van die Bybel geskryf is. Daarin word vir die mens immers allerlei gedragslyne voorgeskryf. Dat die Woord van God die sentrale plek in die lewe van die mens moet inneem, is 'n beginsel wat die Hervorming van die sestiende eeu opnuut na vore gebring is. Uit die Bybel het Johannes Calvyn dan ook 'n aantal stelreëls geput wat, volgens sy beskouing, op die politieke terrein vir die mens bindend is. Dit sal vir die doel van hierdie kort referaat nie nodig wees om op al die politieke beginsels wat Calvyn so geformuleer het, in te gaan nie. Dit sal voldoende wees as na slegs twee verwys word.

Die eerste is die bepaalde vorm van die staatstruktuur. Dit was 'n saak wat Calvyn bereid was om oor te laat aan die omstandighede waarin ' $n$ volk verkeer. Calvyn was egter burger van die stad Genève, wat 'n republikeinse bestuursvorm gehad het. Hierdie feit het waarskynlik 'n rol gespeel by die formulering van die volgende gedagte wat hy in een van sy geskrifte uitgespreek het: „Ek kom daarvoor uit dat die republikeinse regeringsvorm, hetsy dan suiwer aristokraties, hetsy uit aristokratiese en demokratiese elemente, vir my verreweg verkieslik lyk". ${ }^{\text {) }}$ Dat Calvyn aan 'n republikeinse staatsvorm die voorkeur gegee het, het op die geskiedenis groot invloed uitgeoefen. ' $n$ Mens hoef in hierdie verband slegs te verwys na die stigting van die Verenigde State van Amerika.

Die tweede beginsel waarop Calvyn en sy opvolgers klem gelê het, was die verhouding tussen owerheid en onderdaan. 
In hierdie opsig was die Calviniste van die vernaamste grondleggers van die demokrasie. Veral die Franse Hugenote het die feit na vore gebring dat die owerheid aan die wette van God gebonde is. 'n Hoogtepunt in die formulering van hierdie heginsel is bereik met die verskyning van Du Plessis-Mornay se werk Vindicae Contra Tyrannos. Oor die belangrike aandeel wat die Calviniste gehad het in die stryd om die mag van die owerheid oor sy onderdane beperk te kry, hoef hier slegs na die uitsprake van twee Nederlandse geleerdes verwys te word. Die eerste is dr. A. Kuyper. Hy het geskryf dat „dit beginsel van Gods souvereiniteit (keert) zich... tegen de Staatsovermacht”. Hy het voortgegaan: .,Die Calvinisten drukten dit uit door hun onveranderlijk beweren dat men voor een overheid, die eenig ding tegen God en zijn Woord eischt. niet slechts niet behoeft te wijken, maar haar niet gehoorzamen mag". ${ }^{2}$ Die tweede is dr. D. J. de Groot. Van die Franse Calviniste getuig hy: .. $\mathrm{Zij}$ hebben in een tijd, toen vele vorsten met verzaking van plechtig gezworen eden naar de absolute alleenheerschappij streefden, de fakkel van vrijheid en recht in Europa hoog gehouden. $\mathrm{Zij}$ waren fiere kampvechters voor de in wetten verzekerde constitutionele vrijheden en hebben de grootste ernst gemaakt met de waarheid dat gezag en vrijheid alleen harmonisch zullen samenleven in een staat, waarin Overheid en onderdanen de souvereiniteit van de Hoge God des hemels erkennen en nederig willen buigen voor $\mathrm{Zijn}$ Woord". ${ }^{\mathrm{s}}$ )

Hierdie groot beginsel van die Calvinisme, dat 'n onderdaan die reg het om gehoorsaamheid aan 'n goddelose owerheid op te sê. is gebruik as die vernaamste rede vir die skepping van die Nederlandse republiek in 1581. Deur die bekende Placaet van Verlatinghe het die Nederlanders die Spaanse koning Filips II van sy waardigheid vervalle verklaar. In 'n standaardwerk oor die Nederlandse geskiedenis lees 'n mens die volgende oor hierdie gebeurtenis: „In het ,placaet van verlatinghe'... laat zich ontwaren de invloed van Duplessis-Mornay en van Hubert Languet, de ,monarchomachen' of hestrijders der ,tyrannie' en misschien ook wel die van Calvijn ... die aan de ,magistratus populares', hier de Staten, het recht van opstand toekent, weliswaar alleen voor het hehoud van de godsdienstvrijheid". 
Die Nederlandse republiek wat so tot stand gekom het, was geen demokrasie in die moderne betekenis van die woord nie, dit was eerder 'n aristokrasie waarin slegs 'n betreklike klein deel van die volk seggenskap in die bestuur van die staat gehad het. Nogtans het die individu in die sewentiende eeu in die Nederlandse republiek reeds daardie mate van vryheid geniet wat in geen ander land in Europa gevind is nie.

Dit was hierdie Nederlandse republiek wat in 1652 die blanke volksplanting aan die Kaap gestig het. Laat nou meteen gekonstateer word dat die Oos-Indiese Kompanjie wat die Kaap beheer het, aan die blankes wat hulle daar gevestig het, geen seggenskap in die bestuur van die gebied verleen het nie. In hierdie opsig was die bestuur van die Kaap derhalwe 'n weerspieëling van dié wat in Nederland aangetref is. Nogtans het daar in aansienlike mate vryheid vir die individu geheers. Hierop was die Kapenaars uiters jaloers, soos twee voorvalle uit die agtiende eeu duidelik aangetoon het. Die eerste was die wederregtelike arrestasie in 1707 van Adam Tas en 'n paar ander burgers deur goewerneur W. A. van der Stel. Dit het byna tot 'n soort rebellie gelei, wat met die terugroeping van Van der Stel geëindig het. Die tweede was die arrestasie van die burger Buitendag in 1778 deur die fiskaal Boers. Aan die bekende Patriotte-beweging het dit groot stukrag verleen.

Hierdie beweging was die uitvloeisel van 'n politieke denke, wat hom in die agtiende eeu met toenemende krag onder die volke van Europa begin openbaar het. Die nuwe denke het die weg gebaan vir die oorgang van 'n aristokrasie na 'n demokrasie. In toenemende mate het die gewone lede van die volke begin eis dat hulle seggenskap in die bestuur van die staat sou verkry. Die nuwe denkbeelde het hulle in die tweede helfte van die agtiende eeu ook in Nederland begin openbaar, waar die voorstanders daarvan as "Patriotte" bekend gestaan het. Die groot beginsel wat die Patriotte verkondig het, was dat die politieke mag by die volk berus het, dat die owerheid slegs die dienaar was om uitvoering aan die volkswil te gee en dat sodanige owerheid moes aftree wanneer die volk dit verlang het.

Twee gebeurtenisse het die nuwe politieke opvattings voor 
die einde van die agtiende eeu besonder kragtig gestimuleer. Die eerste was die Amerikaanse Vryheidsoorlog, wat ontstaan het as gevolg van allerlei maatreëls wat die Britse regering, sonder raadpleging vooraf met die bevolking, op die Amerikaanse kolonies wou toepas. Onder die leuse van no taxation without representation het die Amerikaners daarop in 1774 na die wapen gegryp en twee jaar later hulself vry van die gesag van die Britse koning verklaar. Hierdie gebeurtenis het in Nederland 'n diepe indruk gemauk. Nog meer was dit die geval met die tweede gebeurtenis, wat as die Franse Rewolusie bekend staan. Hierdie rewolusie het veral daartoe gelei dat allerlei ou en uitgediende bestuurstelsels verwyder is.

Die nuwe denkbeelde wat so aan die einde van die agtiende eeu groot opgang gemaak het, het gegis sous nuwe wyn in ou leersakke. So groot was inderdaad die gisting dat ook die verre Suid-Afrika daardeur getref is. Reeds in 1778 het 'n eie Patriotte-beweging hom uan die Kaap geopenbaar. Uit 'n vlugskrif wat in hierdie jaar onder die Kapenaars versprei is, blyk duidelik dat die opstellers daarvan diep onder die invloed van die nuwe denkbeeld was. Twee aanhalings daaruit behoort voldoende te wees om dit aan te toon. In die eerste is verklaar dat ,het heil des Volks de opperste wet is, dat de wesentlijkheid van het gesag bestaat in de handhawing der regten van de Onderdanen en van 't gemeene best, dat de sorg der Regeerders meer over het geheel dan over de deelen moet loopen..."4) In die tweede is beweer dat 'n volk, ,het regt heeft om sig teegens Regeerders aan te kanten, denselven af, andere in de plaats te setten, wanneer men bespeurt dat de Maatschappij onder hunne Regeering te gronde gaat..." 3 )

Die eis van die Kapenaars om in die bestuur van hul land geken te word en die weiering van die Oos-Indiese: Kompanjie om daaraan te voldoen, was die oorsaak van dic cerste konstitusionele botsing in die Suid-Afrikaanse geskiedenis. Die laaste jare van die Nederlandse bewind aan die Kaap is gekenmerk deur die verwydering wat daar tussen owerheid en burger ontstaan het, omdat laasgenoemde nie meer gediend was om eenvoudig die nek te buig voor alles wat eersgenoemde verordineer het nie. Hierdie botsing het 'n hoogtepunt in 1795 bereik met die opstand van die burgers van die distrikte Graaff-Reinet en Swellendam teen die gesag 
van die Oos-Indiese Kompanjie. Hulle het nou gebruik gemaak van die beginsel dat die onderdane gehoorsaamheid aan 'n "tirannieke owerheid" kon opsê. Dit het hulle gedoen deur die landdroste wat die gesag van die Kompanjie verteenwoordig het, weg te stuur. In 'n brief het die burgers van GraaffReinet verklaar dat .,zo beweeg ons niet anders als 't laatste droppel bloed te presenteren voor onze Vrijheid, want wij de Compagnie bedank hebben, en onder onze vrije Republiecq willen sorteren". ${ }^{8}$ ) Die Graaff-Reinetters wou graag hul eie sake bestuur en het met die oog hierop 'n "Nationale Vergadering" in die lewe geroep. Daarin sou die "Representanten”, deur "de Volkstem" aangewys, sitting hê. ${ }^{7}$ ) Ook die Swellendammers het hul ,Nationale Vergadering" gestig. ${ }^{8}$ )

Van hierdie eerste pogings van die Afrikaner om sy eie staatstruktuur te skep het niks tereggekom nie, want nog dieselfde jaar, 1795, is die Kaap vir die eerste maal deur Brittanje verower. Met die Vrede van Amiens in 1802 sou die Kaap egter andermaal Hollands word. Die kortstondige bewind van die Bataafse Republiek, soos dit vandag algemeen bekend staan, sou vir die verdere ontwikkeling van die repuhlikeinse gedagte by die Afrikaner van verreikende betekenis wees. Dit is te danke aan die bestuursmaatreëls wat twee manne in die kort tydsbestek van slegs drie jaar getref het. Hulle was kommissaris-general J. A. de Mist en genl. J. W. Janssens. Hulle het ' $n$ aantal bestuursinstellings gemoderniseer en ' $n$ aantal nuwes geskep. Dit alles sou later byna net so deur die Boere-republieke oorgeneem word.

Reeds in 1806 was die Britte terug in Suid-Afrika hierdie keer om vir goed te bly soos hul voorneme was. Hulle het dan ook van die standpunt uitgegaan dat die handjievol Afrikaners so spoedig moontlik geangliseer moes word deur hul taal te onderdruk. alle bestuursinstellings te verander, die jeug in in Britse gees te laat opvoed en hul kerk van sy Nederlands-Calvinistiese karakter te probeer beroof. Hierdic strewe on hulle van hul geestelike invloede los te ruk het al sckere mate van verset by baie Afrikaners uitgelok en so) velvreemding tussen owerheid en onderdaan laat ontstaan, maar dit alles sou nog nie voldoende gewees het om die Afrikaanse volk van totale verdwyning te red nie. Een besondere faktor het veroorsaak dat $n p$ die duur 'n aansienlike 
getal Afrikaners dit nie onder die Britse bestuur kon uithou nie. Dit was die rassebeleid van die Britse regering. Die maatreëls wat aan die oosgrens van die Kaapkolonie getref is om die verhouding tussen blank en nie-blank te reël was sodanig dat baie Afrikaners hulle nie daarmee kon versoen nie. Hieruit het die bekende Groot Trek ontstaan.

Die besluit van die Voortrekkers om hulle aan die gesag van die Britse regering te onttrek het hulle voor die posisie te staan gebring dat hulle ' $n$ eie bestuurstelsel in die lewe moes roep. Al wat hulle gehad het om op terug te val, was hul Calvinistiese lewensbeskouing en die mate van politieke ontwikkeling wat hulle tydens die Nederlandse bewind ondergaan het. Dit het veral die Patriotte-tyd gegeld. Wat die Voortrekkers in verband met die skepping van 'n nuwe staat beoog het, word wel duidelik uit die manifeste wat Piet Retief en Piet Uys uitgevaardig het.

Retief het in sy manifes verklaar: „Wij hebben besloten dat alwaar wij ook gaan mogen, wij de regtvaardige grondregelen van vrijheid zullen ophouden..." ${ }^{\theta}$ )

Uys het weer verklaar: „Wij stellen ons vertrouwen op den alwijzen Regeerder van hemel en aarde, en hebben besloten den zekeren grondslag van onze gereformeerde Christelijke godsdienst aan te kleven ..." Voorts is in hierdie manifes gesê: „Wij zijn voornemens onze Volkplanting te vestigen op dezelfde principes van vrijheid als die angenomen door de Vereenigde Staten van Amerika, onze burgerregulatiën. zoo) ver doenlijk, in werking brengende..." ${ }^{10}$ )

Baie van die Voortrekkers was seuns van die manne wat Patriotte was. Dit was bv. die geval met Piet Retief wie se vader Jacobus Retief 'n prominente Patriot was. Dr. C. Beyers skryf na aanleiding hiervan: „Piet Retief was dus van geboorte Patriot. Blyke van eenheid met die denkwyse van lie Patriotte vind ons o.a. in: (a) Die sterk aanwesigheid by Piet Retief van die idee van die algemene welsyn, meer bepaald die, rust en welvaart' van sy medeburgers naar sy beste vermö te hevorder. (h) Sy nasionale bewustheid wat uitstraal as hy van Suid-Afrika spreek as ,mijn vaderland'. (c) Sy groot vryhcidsin wat geopenbaar word in ... die manifes van 22 Jan. 1837".11)

Hoewel die Voortrekkers geestelik dus taamlik goed 
toegerus was vir die taak om as die skeppers van 'n nuwe staat op te tree, het dit hulle aan die praktiese ervaring ontbreek, $500 s$ wel duidelik hlyk uit die konstitusies wat hulle opgestel het om allerlei politieke sake te reël. Hul godsdienssin het wel vcroorsaak dat hulle mcestal gehoorsaam was aan die besluite wat vir die algemene welsyn geneem was. Hierdie besluite sou geneem word deur die eerste verkose wetgewende liggame wat op Suid-Afrikaanse bodem tot stand gekom het. Reeds op 2 Desember 1836 is die eerste sodanige liggaam deur die trekke van Potgieter en Maritz gekies. Daar is saamgekom .,met de mening om door een algemene volkstem Rechters aan te stellen, die voor het algemene best en vrede zullen moeten waken, die ook te gelijkertijd eene Wetgewende Lichaam zullen uitmaken..." 12)

Na die aankoms van die trek van Retief in April 1837 is daar 'n stap verder gegaan met die skepping van die staatstruktuur. Die vernaamste hiervan was ongetwyfeld die inswering op 6 Junie van Retief tot "Goeverneur en Opperhoofd der Algemeen Vereenigd Leger", van Maritz tot „President Regter van deze Algemeene Vereenigde Leger", en van 'n aantal persone tot "Leden van den Raad van Politie van dezen Algemeene Vereenigde Leger", terwyl die trekkers of "Reizigers van die Vereenigde Leger" gesweer het om ,in alle in (ler tijd to maken wetten door Zijn Edele (Retief) en zijn Raad te zullen cerbiedigen en gehoorzamen, alles naar regt en geregtigheid ..." 13)

Die gebeurtenis van 6 Junie 1837 behoort tot een van die mooiste in die geskiedenis van die Afrikaanse volk. Hier het " $n$ jong volk wat voorheen die voorreg ontsê was om seggenskap in sy eie bestuur te verkry, op doelbewuste wyse daartoe oorgegaan om in omstandighede wat geensins vir 'n behoorlike en geordende politieke lewe bevorderlik was nie, met die daad te toon dat hy nic alleen vry wou wees nie, maar dat hy ook geweet het hoe om 'n behoorlike staatstruktuur te skep. Hierdie iolk het dit kon doen omdat hy oor 'n groot geestelike erfenis boskik het. Daar was in die eerste plaas sy Calvinistiese geloof wat hom geleer het dat "n volk volgens die ordinansies van God moet leef. Daar was in die tweede plaas die tradisie van die Patriotte-vadere dat 'n volk homself moet bestuur. Nog in 1842 het die Voortrekkers aan die Britse goewerneur in dic 
Kaap geskryf dat al die moeilikhede wat hulle genoop het om hul geboorteland te verlaat, herlei moes word tot „deze eenige oorzaak, namelijk het gebrek aan een vertegenwoordigend Gouvernement dat ons geweigerd is geworden door het uitvoerend Goevernement van datzelfde volk, hetwelk hetzelfde voorregt beschouwt als een zijner heiligste burgerregten, en waarvoor elk ware Brit zijn leven laten wil". ${ }^{14}$ )

Die bestuursvorm van 6 Junie 1837 was slegs bedoel om te duur solank die trek nog aan die gang was. Daarom is in 1838, selfs nog voordat Dingaan verslaan was, 'n nuwe grondwet opgestel ,voor den Raad van Representanten van het Volk aan Port Natal en 't omliggende Land". Daarin is voorsiening gemaak vir 'n wetgewende liggaam wat op die duur bekend sou staan as die Volksraad. Verder is daar verwys na die "President van Politie”, maar sy magte en pligte is nie omskryf nie.

Die Natalse republiek was geen lang bestaan beskore gewees nie; dit is na slegs enkele jare deur Brittanje verower. Daarmee is die republikeinse strewe van die Afrikaner egter nie gedoof nie. Republiek het vir hom nou slegs 'n ander naam vir vryheid geword. Wie na vryheid gestreef het, het ook na 'n republiek verlang.

Die strewe van die Afrikaner om sy vryheid en republikeinse bestuursvorm te verkry het eindelik gestalte aangeneem met die stigting van die Transvaalse en die Vrystaatse republiek. Met die opstelling van hul konstitusies het die politieke denke van die Afrikaner 'n nuwe stadium binnegegaan. Tot dusverre was al die konstitusionele proefnemings van die Afrikaner sy eie maaksels. Gebrek aan kennis en ervaring het daartoe gelei dat hy een besondere feit oor die hoof gesien het. Dit was die noodsaaklikheid van 'n sterk uitvoerende mag, omdat die wetgewende mag nouliks onk die behoorlike bestuur van die staat op hom kon neem.

Om hierdie groot moeilikheid te oorkom, is die Afrikaners deur twce Nederlanders gehelp - in die Vrystaat deur Jacobus Groenendaal en in die Transvaal deur Jacobus Stuart. Groenendaal wat die Amerikaanse konstitusie geraadpleeg het, het in die ontwerp wat hy in 1854 vir die Vrystaat opgestel het, voorsiening daarvoor gemaak dat daar 'n behoorlike uitvoerende gesag sou wees aan die hoof waarvan 'n president sou 
staan. In artikels 27 tot 41 is die magte en pligte van die president uiteengesit. Hy sou deur die stemgeregtigde burgers gekies word en sou ,het Hoofd van het Uitvoerend Gezag" wees.

In die konstitusie wat hy in 1858 vir die Transvaalse republiek opgestel het, het Stuart vir die skepping van 'n soortgelyke pos voorsiening gemaak.

Dit is wel nodig om hier te konstateer dat die pos van president tot die tweede helfte van die negentiende eeu aan die politieke tradisie van die Afrikaner heeltemal vreemd was, maar selde nog het 'n vreemde loot wat op die Afrikaanse boom geënt was, hom op so 'n blywende wyse en met sulke heerlike vrugte by die republikeinse strewe aangepas as die presidentskap. Veel van die liefde en die aantreklikheid wat die ideaal van 'n republiek later vir die Afrikaner gehad het, was in die feit geleë dat daar 'n president sou wees wat uit die volk self voortgekom het en wat in tye van krisis en gevaar die rol van 'n ware volksvader kon vervul. Manne soos Brand, Reitz, Steyn en Kruger het almal deur die wyse waarop hulle die taak van president vervul het, die liefde vir die republikeinse bestuursvorm des te dieper in die hart van die Afrikaners laat groei.

Die Vrystaat en die Transvaal het as onafhanklike republieke albei ' $n$ bestaan van minder as 'n halwe eeu gehad. Hierdie kort bestaan was vir die geskiedenis van Suid-Afrika egter van deurslaggewende belang. Dit was so om meer as een rede.

Die vernaamste rede was ongetwyfeld die feit dat die Afrikaners hulle as volk in die twee Republieke volledig kon uitleef. Daar mag nooit vergeet word dat slegs 'n deel van die Afrikaanse volk in die twee Republieke gewoon het nie. In die Kaapkolonie en Natal het daar ook duisende Afrikaners gewoon, waar hulle aan allerlei angliserende invloede onderworpe was. Vir hulle was die bestaan van die twee Republieke egter byna altyd bewus of onbewus 'n inspirasie om vas te hou aan die lewensbeskouing en tradisies van hul volk. Dit is meestal duidelik bewys wanneer sulke Afrikaners na een van die Republieke verhuis het. Daar het hulle onmiddellik van die vernaamste verdedigers van die republikeinse vryheid geword. Vir hierdie vryheid het daar waarskynlik net soveel 
gebore Kapenaars hul lewens opgeoffer as gebore T'ransvalers en Vrystaters.

Die ideaal van die republikeinse vryheid het hom in die gemoed van die Afrikaanse volk net so stewig vasgewortel as 'n kareeboom in 'n klipkoppie. Die Afrikaner kon so uan die wêreld toon waartoe hy op die politieke terrein in staat was. Nadat hy in besoek aan Suid-Afrika gebring het, moes die Brit lord Bryce getuig: „In the Orange Free State I discovered. in 1395, the kind of commonwealth which the fond fancy of the philosophers of last century painted. It is an ideal commonwealth, not in respect of any special excellence in its institutions, but because the economic and social conditions which have made democracy so far from an unmixed success in the American States and in the larger Colonies of Britain, not to speak of the people of Europe, whether ancient or modern, have not come into existence here..." ${ }^{1 "}$ )

Dat die Afrikaners hul republikeinse vryheid werklik op prys gestel het, het duidelik gehlyk nadat sir Theophilus Shepstone op 12 April 1877 oorgegaan het tot die anneksasie van die Transvaal. Dit het soos 'n vuishou op die neus getref en onder die leiding van Paul Kruger het die Transvalers hulle gereed gemaak $\mathrm{nm}$ die kosbare kleinood wat hulle verloor het, desnoods met wapengeweld terug te kry. Hoedanig die gees was wat die Transvalers hesiel het, blyk duidelik uit 'n memorie wat namens hulle aan die Vrystaatse Volksraad gestuur is en wat deur hierdie liggaam op 21 Februarie 1881 behandel is. Dit was een van die gevoelvolste uitings van die gees van nasionalisme wat nou oor die Afrikaanse volk as geheel vaardig geword het. ' $n$ Volk het in alle opsigte selfbewus geword en het hom daarom begin rekenskap gee van die faktore wat tot sy ontstaan aanleiding gegee het. Die stuk het met die vraag begin: "Wie zijn wij?" Die antwoord daarop is self gegee: „Afstammelingen van de Hollandsche Kolonisten van de Kaup de Goede Hoop, en hestaande uit zuivere Hollandsche mannen en uit nakumelingen van de Refugies... Uit deze twee stammen groeide één volk op, één in geloof, fén in rustigen eerbied voor de Wet, maar met een gevoel van vrijheid en onafhankelijkheid, even grootsch als de vlakten ruim waren". Die dokument is met die volgende fiere woorde afgesluit: „Met vertrouwen leggen wij onze zaak voor de 
geheele wereld. Hetzij wij overwinnen, hetzij wij sterven: de Vrijheid zal in Afrika rijzen als de zon uit de morgenwolken, als de vrijheid rees in de Vereenigde Staten van NoordAmerika. Dan zal het zijn van Zambezi tot aan Simonsbaai: AFRIKA VOOR DEN AFRIKANER".16)

Die vryheidstryd van die Transvalers en die militêre oorwinnings wat hulle behaal het, beteken in die wordingsgeskiedenis van die Afrikaanse volk een van die vernaamste mylpale. Dit het 'n gevoel van eenheid van die Limpopo tot aan Kaap Agulhas laat ontstaan. En hierdie gevoel het die republikeinse tradisie soveel sterker laat staan. Dit blyk duidelik uit wat die skepper van die Afrikanerbond, ds. S. J. du Toit, in hierdie tydperk geskryf het. In sy toeligting tot die program van beginsels van hierdie politieke organisasie het ds. Du Toit geskryf dat, „wanneer met het oog op de toekomstige vereniging van Zuid-Afrika..., de vraag aan de orde komt: welke regeringsvorm wij alsdan zouden verkiezen, dan zeggen wij met Calvijn dat ook ons de voorkeur aan de republiek schijnt toe te komen..." Ds. Du Toit het drie redes genoem waarom aan die Republikeinse bestuursvorm die voorkeur gegee moes word. Ten eerste, ,de republikeinse regeringsvorm is geworteld in onze volkshistorie". Ten tweede, "de Republiek komt het best overcen met onze Volksaard". Ten derde, „de Republiek (is) de enig denkbare staatsvorm voor een Vereenigd Zuid-Afrika". ${ }^{17}$ )

Die vordering wat die republikeinse gedagte in die laaste twintig jaar van die negentiende eeu gemaak het, was ongetwyfeld een van die vernaamste redes waarom die draers van die Britse imperialistiese gedagte dit as hul vernaamste vyand gesien het en waarom hulle begin afstuur het op die vernietiging van die onafhanklikheid van die twee Boere-republieke. 'n Suid-Afrika wat ook onafhanklike republieke gehad het, was volgens hul opvattings nie veilig in die besit van Brittanje nie. Word die onafhanklikheid van die twee Republieke vernietig, sou dit ook die einde van die republikeinse gedagte wees. En die einde van die republikeinse gedagte sou die verdwyning van die Afrikaanse volk meebring, omdat hy dan sy groot politieke stukrag sou verloor, sodat hy des te makliker geangliseer kon word.

So het aan die einde van 1899 'n verwoestende oorlog op 
Suid-Afrika toegesak. Die Britse imperialiste kon hul eerste doel, die vernietiging van die onafhanklikheid van die twee Republieke, bereik. Met die Vrede van Vereeniging op $31 \mathrm{Mei}$ 1902 het die Vrystaat en die Transvaal Britse kolonies geword. Die Britse imperialiste het aanvanklik gemeen dat hulle ook hul tweede oogmerk bereik gehad het, nl. die vernietiging van die republikeinse gedagte. Oppervlakkig beskou het dit werklik so gelyk, maar dit was slegs skyn. Daarom moes ook die biograaf van genl. Botha in latere jare erken: „Hoe het daar nie vir "n lang tyd in so baje huisgesinne van die vroeëre Boerestate in die aandgebed 'n smeekklank opgestyg vir die herstel van die ou republikeinse orde van sake nie". ${ }^{18}$ ) Baie Afrikaners het na 1902 ongetwyfeld van die republikeinse ideaal afstand gedoen, maar dit was waarskynlik 'n minderheid. Diegene wat daaraan trou gebly het, het in die toenmalige omstandighede dit beter geag om die voorbeeld te volg van die Franse volk, wat na die verlies van die twee provinsies die Elsas en Lotaringe in $187 \mathrm{l}$ as stelreël aanvaar het om nooit daarvan te praat nie maar om altyd daaraan te dink.

Omdat die republikeinse ideaal in die harte van die meerderheid van die Afrikaners voortgeleef het en omdat 'n republiek vir hulle sinoniem met onafhanklikheid was, was dit vir die Britse imperialiste nie moontlik om hul einddoel, die verdwyning van die Afrikaanse volk deur dit te angliseer en Suid-Afrika so veilig vir Brittanje te maak, te bereik nie. In stede van om tot geestelike kapitulasie oor te gaan, het die Afrikaner 'n groot kultuurstryd begin om sy identiteit te behou.

In hierdie opsig het die politieke eenwording van SuidAfrika op 31 Mei 1910 die Afrikaner goed te stade gekom. Die onderliggende gedagte met unifikasie was om Suid-Afrika heeltemal veilig vir Brittanje te maak. Dit was immers die bekroning van die strewe van soveel Britse staatsmanne sedert die begin van dif Iweede helfte van die negentiende eeu. En met unifikasie is nou verwag dat die Afrikaner bereid sou wees om maar in die groter Britse geheel op te gaan. Op 29 Oktober 1932 het mnr. G. Heaton Nicholls, een van die vernaamste verteenwoordigers van die imperialistiese rigting, nog in 'n toespraak verklaar: ,At Union a dual language was ugreed upon. The English thought that this was merely a 
concession to sentiment. that English would be the tongue of the future... We had gone about talking about the South African nation which would consist of British and Dutch; but at the back of our minds we all supposed they would all talk English". ${ }^{10}$ )

Teen die verwagting in van die imperialiste het die Afrikaner wat in politieke leier in genl. J. B. M. Hertzog gevind het. ' $n$ stryd hegin wat vandag gesien moet word as die voorspel tot die uiteindelike seëviering van die republikeinse ideaal. Genl. Hertzog het twee groot oogmerke gehad: volkome kulturele en taalgelykheid vir Afrikaans- en Engelssprekendes en die reëling van die konstitusionele posisie tussen Brittanje en die Unie, sodat laasgenoemde internasionaal as n soewereine en onafhanklike staat prken sou word. Omdat hierdie doelstellings van genl. Hertzog nie die goedkeuring van genls. Botha en Smuts weggedra het nie. het daar 'n skeuring tussen hulle ontstaan. Dit het tot gevolg gehad dat die Nasionale Party op in kongres wat op 7 en 8 Januarie 1914 gehou is, in die lewe geroep is.

Oor die tydperk van ruim in halwe eeu was die Nasionale Party nou dip draer van die groot politieke aspirasies van die Afrikaanse volk. Soos dit met enige ander volk die geval is, was daar in hierdie aspirasies ook groei en verandering. Met verloop van tyd kan sake immers in 'n beter perspektiei gesien word. Daarom vind ' $n$ mens ook dat daar aanvanklik geen sprake was dat die Nasionale Party die herstel van die republikeinse onafhanklikheid nagestreef het nie. In die bekende artikel 4 van die program van beginsels het die Nasionale Party dan ook slegs beong on die konstitusionele verhouding tussen Brittanje en die Unie sodanig gereël te kry lat daar van die onderhorigheid van laasgennemde geen sprake meer sou wees nie. Die artikel het as volg gelui: „De positie van de Unip ten opzichte van hare hetrekkingen tegenover 't Verenigde Koninkrijk. Lerustende op de goede trouw van twee naties, wordt door haar (dic Nasionale Party) zonder umweg erkend en zij grevoelt zich ervan overtuigd dat de handhaving van die goede verstandhouding tussen de Unie en t Rijk afhanklik is van de nauwgezette vermijding van enige handeling waardoor 't volk der Unie in zijn staatkundige vrijheid wordt verkort of belemmerd of waardoor enige der 
vrijheden van 't land of diens regering onttrokken worden aan 't onmiddellijk gezag of beheer van 't volk der Unie".

Al het die Nasionale Party nou ook nie die republikeinse ideaal aanvaar nie, is binne 'n paar maande na sy stigting nogtans geopenbaar dat 'n groot deel van die Afrikaanse volk aan sy verlede getrou gebly het. In Augustus 1914 het die Eerste Wêreldoorlog uitgebreek. Die Britse regering het daarop 'n versoek tot die Unie-regering, waarvan genl. Botha die hoof was, gerig om Duits-Suidwes-Afrika militêr te laat beset. Hieraan is gehoor gegee. In die oë van duisende Afrikaners was dit 'n immorele daad. In die bekende proklamasie van Steenbokfontein wat op 29 Oktober 1914 in die naam van genls. De Wet en Beyers uitgereik is, is verklaar dat „Gods vloek ons treffen zal, indien dit besluit van de Regering ten uitvoer gebracht wordt". ${ }^{\circ}$ ) Daar is teruggegryp na die ou Calvinistiese beginsel van die reg van opstand teen 'n goddelose owerheid. So het genl. De Wet verklaar: „Nou voel ek dat, as ek myself getrou wil wees voor God en mens, dan moet ek my vinger steek in die oog van God of in die oog van Lewies Botha en ek sal hom steek in die oog van Botha wat alleen my liggaam en nie my siel kan seer maak nie".21) Die opstand teen 'n goddelose regering het die Afrikaners weer aan hul republikeinse verlede laat dink. Wie gerebelleer het, het gemeen om van Suid-Afrika 'n republiek te maak.

Die Rebellie het op 'n klaaglike mislukking uitgeloop. Militêr was daar nooit selfs die geringste kans dat dit sou slaag nie. Nogtans is daar uit hierdie opstand groot gevolge gebore. In die geskiedenis van volke gebeur dit immers meermale dat uit nederlae of mislukkings daar gevolge voortvloei wat 'n keerpunt ten goede beteken. Dit was ook die geval met die Rebellie. Dit was immers hierdie gebeurtenis wat gelei het tot daardie grootste strewe na selfredding, nl. die Helpmekaar. So het die Rebellie ook die Afrikaanse volk laat terugkeer na die republikeinse ideaal. Hoe langer die oorlog geduur het, hoe groter het ook die aandrang geword dat daar op aktiewe maar konstitusionele wyse na die verkryging van 'n republiek in Suid-Afrika gestreef moes word. Hierdie aandrang van hul volgelinge het die leiers van die Nasionale Party in 'n enigsins moeilike posisie geplaas, want hulle was bevrees dat die anvaarding van die republikeinse ideaal in 
die heersende omstandighede dit heeltemal onmoontlik sou maak dat hulle aan die bewind kon kom.

(jenl. Hertzog het gemeen dat hy met 'n ander oogmerk meer sukses kon behaal. Dit was om die beginsel te verkondig dat Suid-Afrika in generlei opsig aan Brittanje onderhorig was nie. Hierdie heginsel het hy vir die eerste maal verkondig in twee toesprake wat hy op 4 en 11 Mei 1917 voor die Stellenbosse studente gehou het. Genl. Hertzog het by hierdie geleentheid verklaar dat ,wij zijn een zelfregerende Staat met eigen Parlement en eigen Regering. Brits zijn wij in Staatsrechtelijke zin alleen in zoverre als wij staan onder die Britse Kroon... niet onder het Britse Parlement, ook niet onder de Britse Regering. Aan de zijde van deze, maar geenszins onder hen, staan wij onder de Koning van Engeland, als zijnde ook onze Souvereine Vorst..." Genl. Hertzog het uit hierdie beginsel wat hy geformuleer het, die verdere afleiding gemaak dat die Inie nok neutraal in 'n oorlog van Brittanje knn bly. ${ }^{33}$ )

Ten spyte van dic verkondiging van die heginsel deur genl. Hertzog dat die Unie nie aan Brittanje onderhorig was nie, moes hy en ander Nasionale leiers nogtans kennis neem van wat in die gemoed van die Afrikaanse volk oor 'n repuhliek omgegaan het. Daarom was die Federale Raad verplig on op 16 Julie 1917 'n verklaring uit te reik waarin erken is dat „,bij een zeer aanzienlijk gedeelte van de bevolking van Zuid-Afrika er een sterke drang bestaat naar onafhanklijkheid". Daarom is ,, het bestaan van een republikeins gevoel... verklaarbaar en geoorloofd" beskou. Tog het die Federale Raad dit in die hecrsende oorlogsomstandighede nie raadsaam gevind dat daar aktirwe propaganda vir 'n republiek gemaak soul word nie. ${ }^{23}$ ).

Aan die einde van 1918 is die bloedige stryd in Europa gestaak. Dic oorwinnaars, wat 'n hele reeks drastiese politieke veranderings wou mak, het daarop met die kreet van die selfbeskikkingsreg van volke gekom. Dit het hy die Afrikaner weerklank gevind. Indien aan ander volke die reg vergun sou word on oor hul eie posisic te beskik, waarom dan nie ook aan hom nie? Hierdie vraag het daartoe gelei dat vroeg in 1919 ' $n$ groot kongres in Bloemfontein gehou is waarop besluit is om ' $n$ afvaardiging met genl. Hertzog aan die hoof 
na die vredemakers in Parys te stuur met die versoek om die geskonde republikeinse onafhanklikheid in Suid-Afrika te herstel. Die antwoord wat die afvaardiging van Lloyd George, die destydse eerste minister van Brittanje, ontvang het, was: "The Constitution of the new Union was the free act of the whole people of South Africa representing both white races and all the Colonies". ${ }^{24}$ )

Vir genl. Hertzog was hierdie antwoord van kardinale belang. Indien Suid-Afrika vry was om sy eie heil uit te werk, dan moes daar gesorg word dat dit bo alle twyfel verhewe sou word deur dit swart op wit vas te lê. Genl. Hertzog se kans het gekom nadat hy in 1924 Eerste Minister geword het. In 1926 sou daar 'n rykskonferensie plaasvind, waarop genl. Hertzog van plan was om die saak aanhangig te maak. Voor sy vertrek na Brittanje het genl. Hertzog in 'n toespraak wat hy in Stellenbosch gehou het, die volgende verklaar: „Ten spyte van ons vrye en gelyke status met Groot-Brittanje bly ons... in die ö̈ van die buitewêreld afhanklik van die Britse soewereiniteit". Hy wou derhalwe op die rykskonferensie ' $n$ verklaring vra om alle onduidelikheid oor hierdie saak uit die weg te ruim. ${ }^{25}$ )

Genl. Hertzog het sy sin gekry. Deur die rykskonferensie is ' $n$ verklaring opgestel waarin van Suid-Afrika en die ander dominiums die volgende gesê is: „They are autonomous Communities within the British Empire, equal in status, in no way subordinate to another in any aspect of their domestic or external affairs, though united by a common allegiance to the Crown and freely associated as members of the British Commonwealth of Nations". ${ }^{2 \theta}$ )

In die konstitusionele ontwikkeling van Suid-Afrika is die verklaring van die rykskonferensie van 1926 sonder die minste twyfel een van die belangrikste gebeurtenisse. Bo alle twyfel verhewe is daardeur aan die hele wêreld vertel dat. die Unie van Suid-Afrika 'n soewereine en onafhanklike staat was wat sy eie heil kon uitwerk. Dat hierdie feit erken is, was uitsluitlik die werk van genl. Hertzog. Daarvoor behoort sy nagedagtenis altyd die dank en waardering van elke Afrikaner te geniet. Tog het die verklaring van die rykskonferensie, hoewel dit destyds nie onmiddellik duidelik was nie, in die geledere van die Afrikaners verdeeldheid gebring. Was die 
verklaring die eindpaal van Suid-Afrika se konstitusionele ontwikkeling of was dit slegs 'n mylpaal? Moes Suid-Afrika 'n soewerein-onafhanklike monargie bly met erkenning van die Britse koningskap of moes daar van die vryheid gebruik gemaak word om 'n republiek te verkry wat in generlei opsig aan die Britse kroon of Ryk verbind was nie? Oor hierdie vrae sou daar binne enkele jare 'n nuwe stryd ontbrand.

Vir genl. Hertzog persoonlik het dit vasgestaan dat die Unie ten opsigte van sy konstitusionele ontwikkeling die eindpaal bereik het. Met sy terugkeer in Kaapstad het hy in 'n toespraak gesê: „Ons is 'n vrye volk wat alleen solank en sover met die Ryk hoef saam te werk as ons vrye wil en ons eie belang vasstel. $\mathrm{U}$ moet dus nie skrik as ek u eendag sê dat ek is 'n volslae Imperialis nie. As u my gaan vra wat my beleid is, sal ek u dadelik sê dat ek nie ses beter makkers kan kry om mee saam te werk as wat ons nou mee saamwerk nie". ${ }^{27}$ ) Hiermee het genl. Hertzog bedoel Brittanje en die ander dominiums. Aan die verkryging van 'n republiek het genl. Hertzog dus nie meer gedink nie.

Dit was hier waar die paaie van genl. Hertzog en baie Afrikaners uiteen begin loop het. Hulle kon die verklaring van die rykskonferensie alleen as 'n mylpaal aanvaar. Dit was hul beskouing dat as die verklaring as die eindpaal gesien word, daar dan ook afstand gedoen moes word van die groot politieke ideaal van die Afrikaanse volk, wat vryheid steeds vereenselwig het met die republikeinse staatsvorm. Kan daar nou van die Afrikaners verwag word om tevrede te wees met vryheid wat verbind is aan die monargale staatsvorm? Kan daar van die Afrikaner wat met wapengeweld van sy republikeinse staatsvorm beroof is, verwag word om liefde en trou te betuig aan 'n vreemde vors wat met die beste wil van die wêreld geen simpatie vir sy nasionale aspirasies kan voel nie?

Van die Afrikaners wat hierdie vrae gestel het, het dr. $\mathbf{N}$. J. van der Merwe die tolk geword, toe hy in die pers geskryf het: „Genl. Hertzog gaan na die Rykskonferensie en keer terug met die versekering: ,Die dag het aangebreek. Ons soewereine onafhanklikheid is verkry'. En Suid-Afrika juig asof hy reeds die goue strale van die môre versterkend en besielend ondervind. En tog! En tog! En tog! Is dit waarlik die lang 
verwagte dag? Is dit die lieflike gedaante van vryheid waarvoor daar soveel trane en bloed in die verlede gestort is? Kan ons nou oortuig wees dat die ,las van Duma' nie verder op ons van toepassing is nie? Ek wag nog op die antwoord van die wagter. Ek hou my siel vas uit vrees dat daar op dic gesegde: „Die môre het gekom', weer die somber woorde sal val: .Maar dit is nog nag' ".".s)

Dit was inderdaad 'n juiste siening van die toestand. Die vryheid met die vorm waarin dit gegiet was, kon baie Afrikaners nie bekoor nie -- selfs nie eens nadat die vryheid hehoorlik in wetgewing omskryf was nie. In die geledere van die Nasionale Party is so op die duur spanning veroorsaak. In 1933 het die breekpunt eindelik gekom nadat genl. Hertzog - deur die ekonomiese omstandighede daartoe gedryf - besluit het om 'n koalisie met genl. Smuts aan te gaan. Dit het op sy beurt in 1934 uitgeloop op die stigting van wat vandag algemeen bekend staan as die Verenigde Party.

Groot getalle Afrikaners kon hulle met hierdie stap nie vereenselwig nie en het besluit om die Nasionale Party to handhaaf. Wanneer na byna dertig jaar op hierdie gebeurtenisse teruggekyk word. dan is dit duidelik dat die skeuring wat in die geledere van die Nasionale Party ontstaan het, vir hom ook 'n verjongingskuur beteken het. wat hom des te beter in staat gestel het om as die vertolker op te tree van wat diep in die gemoed van die Afrikaanse volk omgegaan het.

Die beste het dit tot uiting gekom in die openlike aanvaarding van die republikeinse ideaal as een van die vernaamste doelstellings van die Nasionale Party. In 1936 is in die nuwe program van heginsels die republikeinse ideaal as volg omskryf: „Die Party erken onomwonde die reg van die volk om te eniger tyd as hy dit in die belang van die land ag. sy regeringsvorm langs konstitusionele weg te verander. Die Party is daarvan oortuig dat die republikeinse staatsvorm, afgeskei van die Britse Kroon, hom die beste aanpas by die tradisies, omstandighede en aspirasies van die Suid-Afrikaanse volk en daarom sal hy die republikeinse ideaal beskerm en hom beywer om 'n republiek in Suid-Afrika tot stand te bring. Hy erken dat 'n republiek tot stand gebring kan word alleen op die breë grondslag van die volkswil en met die getroule inagneming van dic gelyke taalregte van die 
twee seksies van die blanke bevolking. In ooreenstemming hiermee lê hy vas dat hierdie konstitusionele verandering tot stand gebring sal word alleen ingevolge ' $n$ spesiale en besliste opdrag daartoe van die volk".

Die aanvaarding van hierdie artikel deur die Nasionale Party moet vandag as een van die belangrikste gebeurtenisse in die geskiedenis van Suid-Afrika gesien word. Vir die eerste maal het 'n politieke party nou openlik as ideaal aanvaar om van Suid-Afrika 'n republiek te maak. Vir die verwesenliking van hierdie ideaal was dit 'n enorme stap vooruit dat die Nasionale Party nou as sy kampvegter sou optree. Dit het onmiddellik tot gevolg gehad dat die republikeinse ideaal een van die vernaamste strydpunte tussen die partye geword het.

Nogtans het dit in 1936 en in die jare wat onmiddellik daarop gevolg het, soms gelyk of die koms van die republiek 'n verre ideaal sou bly. In 1939 het die Tweede Wêreldoorlog uitgebreek, en daarmee het die imperialistiese rigting onder leiding van genl. Smuts ook sy hoogste triomf beleef. Deur middel van die meerderheid wat hy in die Volksraad verkry het, kon genl. Smuts Suid-Afrika aan die kant van Brittanje aan die oorlog laat deelneem. Vandag kan natuurlik gekonstateer word dat dit onk die laaste oorwinning van die imperialisme in Suid-Afrika was. Vir die republikeinsgesinde Afrikaner was die oorlogsjare inderdaad soos 'n donker nag, want in sy eie geledere het daar stryd en botsing geheers 'n stryd wat, soos vandag wel duidelik behoort te wees, heeltemal onnodig was.

Die einde van die oorlog het gelukkig egter ook 'n einde aan die stryd onder die republikeinsgesinde Afrikaners gehring, en so kon die algemene verkiesing van 26 Mei 1948 met aansienlike mate van eensgesindheid tegemoet gegaan word. So kon 'n groot keerpunt bewerkstellig word. Die Nasionale Party wat hom in sy program van beginsels vir die verkryging van ' $n$ republiek gebind het, het onder leiding van dr. D. F. Malan die oorwinning behaal en die bewind oorgeneem.

Dit was die beleid van die nuwe regering om SuidAfrika stap vir stap op die weg na 'n republiek te voer. 
Dergelike stappe was die instelling van 'n eie Suid-Afrikaanse hurgerskap, die afskaffing van die reg van appèl van die Suid-Afrikaanse hone na die Britse Geheime Raad, die aanvaarding van slegs een Suid-Afrikaanse vlag, die bepaling dat Die Stem die Suid-Afrikannse volkslied sou wees, die oorname van die vloothasis by Simonstad en die skepping van 'n eie muntstelsel. Al hierdie stappe het aangetoon dat die koms van die republiek unafwendbaar was.

Eindelik kun die Eerste Minister, dr. H. F. Verwoerd, op 20 Januarie 1960 in die Volksraad aankondig dat die republikeinse vraagstuk, soos hy dit gestel het „binne die terrein van die praktiese politiek" gekom het. Dr. Verwoerd het voortgegaan: „Ek kundig dus aan dat die vraag aan die Volk sal gestel word by wyse van 'n volkstemming, 'n referendum". Die stemming is op 5 Oktober 1960 gehou. 850,000 kiesers het hulle ten gunste van die verandering na in republiek verklaar. terwyl 775,000 daarteen was. Die uitslag van die referendum het dus duidelik aan die lig gebring dat die republikeinse ideaal our alle teenstand geseëvier het. Die oorspronklike bedoeling was dat die Republiek van Suid-Afrika om voortdurende lidmaatskap van die Britse Statebond aansoek sou doen. Toe hy met hierdie doel voor oë 'n konferensie in Londen bygewoon het. was die teenstand van die verteenwoordigers van sekere lande egter so groot dat dr. Verwoerd op 15 Maart 1961 die aunsuek teruggetrek het. Dit het derhalwe die finale verbreking van alle staatkundige bande tussen Brittanje en Suid-Afrika beteken. Op 31 Mei 1961 het die Republiek van Suid-Afrika sy bestaan formeel begin.

Die blanke volksplanting aan die voet van Tafelberg is begin deur manne wat verteenwoordigers van 'n republiek was wat op bepaalde heginsels gevestig was. Daarvan was die Christelike geloof ongetwy feld die vernaamste. Oor 'n tydperk van drie eeue het hierdie beginsels gedien om die republikeinse ideaal op Suid-Afrikaanse hodem tot volle wasdom te laat kom. Die Republiek van Suid-Afrika kan alleen dan 'n toekoms hê. indien daar steeds gesteun word op dié beginsels wat oor Amsterdam en Genève gekom het van Rome, Athene en Jerusalem.

Johamnesburg.

G. D. Scholtr. 


\section{VERWYSINGS:}

1) Dr. A. Kuyper: Het Calvinisme Oorsprong en Waarborg onzas Constitutioneele Vrijheden (Amsterdam, 1874), bl. 11.

2) Kuyper, bl. 53.

3) Dr. D. J. de Groot: De Reformatie en de Staatkunde (Franeker, 1955 ), bl. 246.

4) Dr. Coenraad Beyers: Die Kaapse Patriotte 1779-1791 (Kaapstad, 1929), bl. 204.

5) Beyers, bl. 207.

6) Dr. P. A. C. Witringa: De Oudste Boeren-Kepublieken (Den Haag, 1921), bl. 107.

i) Wier inga, bl. 45.

8) Argief Kaapstad: Sw 12/90. bl. 38-40.

9) De Zuid.Afrikaan, 17-2-37.

10) De Zuid-Afrikaan, 27-10-37.

11) Beyers, bl. 166-67.

12) G. S. Preller: Voortrekkermense I (Kaapstad, 1920), bl. 297.

13) The South African Commercial Advertiser, 29-7-37.

14) J. Stuart: De Hollandsche Afrikanen en Hunne Republiek in Zuid-Afrika (Amsterdam, 1854), bl. 154-55.

15) James Bryce: Impressions of South Africa (Londen, 1899), bl. 314.

16) G. D. Scholtz: President Johannes Henricus Brand (Johannesburg, 1954), bl. 215-16.

17) J. D. du Toit: Ds. S. J. du Toit in Weg en Werk (Paarl. 1917), bl. 191 .

18) Dr. F. V. Engelenburg: Generaal I.oujs Botha (Pretoria, 1928), bl. 218 .

(4) The Rand Daily Mail. 31-10-32

20) G. D. Scholtz: Die Rebellie 1014-15 (Johannesburg. 1942), b]. 197.

$21)$ S. P. F. Boshoff: Rebelliesketse (Pretoria. 1918), bl. 29.

22) De Burger, 5-5.17 en 12-5.17.

23) De Burger, 20-7-17.

24) L. E. Neame: General Hertzog (londen, onnder jaartal), bl. 208.

2.5) Die Burger. 17-5-26.

26) Britse blouboek Cmd 2768, bl. 14.

27) Die Burger. 14-J2-26.

2B) G. D. Scholtz: Dr. Nicolaas Johannes van der Merwe (Johannexburq. 1944). bl. 85. 